\title{
CHRONIC NEUROLOGICAL DISEASE AS A POSSIBLE FORM OF LEAD POISONING
}

\author{
BY \\ E. J. BUTLER \\ From the Departments of Neurology and Biochemisiry, \\ the Radcliffe Infirmary, Oxford
}

It has long been known that the clinical manifestations of lesions in the nervous system produced by lead are diverse and may simulate the symptoms of various chronic neurological diseases. This suggested to early workers that lead might be an aetiological agent in such diseases.

Later, the failure to demonstrate the presence of other features of classical lead poisoning such as colic, anaemia, and basophilic stippling of the red cells in these conditions, and any correlation with exposure to an occupational hazard, demanded the modification of the original theory, and there remained the possibility that lead ingested in subtoxic amounts may eventually produce these chronic, atypical forms of poisoning.

Disseminated sclerosis is a particular example. The old theory championed by Oppenheim that lead is the causative factor was revived in a modified form by Cone, Russel, and Harwood (1934), who suggested that the demyelination is produced by lead which is mobilized from skeletal deposits before relapse. They put forward analytical results in support of this view. Lead was detected in the cerebrospinal fluid of six out of eight patients with this disease, and was-estimated in the faeces and urine and also in the spinal cord of another patient. Their results for cerebrospinal fluid are not in agreement with those of Rabinowitch, Dingwall, and Mackay (1933) and Boshes (1935).

However, with the advent of more accurate and sensitive analytical methods it was realized that the findings of Cone and others were of no aetiological significance since similar amounts of lead may occur in most normal human fluids and tissue "as an inevitable consequence of life on a lead-bearing planet" (Kehoe, Thamann, and Cholak, 1933).

A new light was thrown on human demyelinating diseases by the discovery that swayback, a similar disease of lambs, was associated either with a dietary deficiency of copper or with a defect in its utilization by the nervous system, and could be prevented by the administration of copper to the pregnant ewe. Since the incidence of the disease tended to follow the geological occurrence of lead in Derbyshire and the sheep were found to have absorbed abnormal amounts of this metal from their diet, it was suggested that lead might be involved in the production of the disease (Innes and Shearer, 1940 ; Shearer and McDougall, 1944). This view has never been confirmed.

Campbell, Herdan, Tatlow, and Whittle (1950) reported that teeth from patients with disseminated sclerosis contained on the average a significantly higher concentration of lead than was present in the teeth of normal healthy people. They discovered a high incidence of this disease in a village where the concentration of "acetic acid soluble lead" in the garden soil was high, though the well water was not contaminated, and concluded that lead might be an aetiological factor in some cases, perhaps by antagonizing the utilization of an essential metal.

However, large skeletal deposits of lead do not necessarily indicate intoxication since they are themselves physiologically inert. The possibility that the physiological changes accompanying chronic diseases may promote the deposition of metals in the skeleton should be borne in mind, This is illustrated by the increased deposition of zinc in teeth in tuberculosis (Cruickshank, 1940).

Cases of lead myelopathy with symptoms closely similar to those of disseminated sclerosis have been described by Cone and others, by Williams (1939), and by Campbell and others. The diagnosis was based on the finding of a high concentration of lead in the fluids or tissues and the recognition of a hazard. Other points of similarity between the two conditions are the frequent increase in the concentration of cerebrospinal fluid proteins and the lowering of the platelet count (literature cited by Campbell and others).

Analogous theories of the production of acute transverse myelitis (quoted by Campbell and others). and of toxaemia of pregnancy (Letonoff, Reinhold, 
Riggs, and Cohn, 1940) in certain people may be quoted, and the analysis of tissue taken at necropsy has given some support to such speculation. Hansmann and Perry (1940), from their study of the relative concentrations of lead in liver and rib, concluded that lead which has been mobilized from skeletal deposits may act as an unrecognized factor in many diseases, although it may not be possible to trace any abnormal exposure. Riggs, Letonoff, and Reinhold (1944) formed a similar opinion from their results on kidney and pituitary gland obtained from patients whose death was not adequately explained by clinical and necropsy findings. Many of them had presented neurological symptoms.

The dangers of de-leading treatment after lead poisoning have been much discussed and are relevant to this problem. Aub (1935) drew attention to the possibility that the mobilized lead may not be excreted but may circulate and be redeposited, and Kehoe (quoted by Gray, 1935) has emphasized the danger of redeposition in the nervous system.

It is apparent that this theory of the aetiology of disseminated sclerosis and other neurological conditions is only supported by circumstantial evidence, yet it has never been satisfactorily dismissed, and a direct investigation using a reliable analytical method was undertaken to fulfil an obvious need. The postulated mobilization of lead from the skeleton in toxic quantities must inevitably produce an increase in the amount of lead in circulation and this may result in an increased excretion. Accordingly the concentration of lead in the blood and cerebrospinal fluid of various patients and their urinary excretion of lead was determined. Information on the magnitude of skeletal deposits of lead in certain patients was obtained by the analysis of biopsy specimens of tibia and of teeth. The urinary excretion of coproporphyrin was also studied, since de Langen and ten Berg (1948) had shown that its elevation is an early sign of the absorption of abnormal amounts of lead, and it was argued that it should also be a sensitive indication of lead mobilization.

The estimation of lead in post-mortem specimens of tissue taken from people whose diagnosis is beyond doubt is obviously essential, yet apart from the single analysis of spinal cord recorded by Cone and others (1934) no such investigation of disseminated sclerosis has ever been reported. Values for the lead content of brain, spinal cord, liver, and bone taken from people who had undoubtedly suffered from disseminated sclerosis are presented in this paper.

\section{Material}

The subjects studied fall into four groups :-

(1) Disseminated Sclerosis.-This group includes 26 patients with disseminated sclerosis and five probable cases. The majority of these and the other neurological cases in the second group have been under observation since they were investigated and their diagnosis was recently checked personally by Dr. W. Ritchie Russell. Cases of spastic paraplegia which have not shown the characteristic relapses and remissions of disseminated sclerosis are included in the next group.

The age of these subjects at investigation ranged from 20 to 54 years, their average age being 37 years, and the duration of the disease varied from one month to 25 years (average six and a half years).

Tissue samples were obtained from five additional subjects post-mortem, and in each case the diagnosis of disseminated sclerosis was confirmed histologically by Drs. P. M. Daniel and F. D. Bosanquet.

(2) Miscellaneous Neurological.-This group contains 56 patients with other chronic neurological diseases, some of which, e.g. spastic paraplegia and peripheral neuritis, may be simulated by lead poisoning. Six children are included and the average age of the adults at investigation was 42 years. Necropsy tissue samples were obtained from two of the adults.

(3) Patients with Unusual Exposure to Lead.Investigations were carried out on seven patients with slight non-specific symptoms, of whom six had experienced an occupational exposure to lead. The other patient (C.H.) was included in this group on the grounds that his high intake of beer (more than a gallon a day) for 38 years may have constituted an abnormal exposure which was responsible for his high lead excretion. Beer which has been contaminated by lead pipes has been known to produce poisoning when consumed in such quantities.

The analytical results obtained for these cases and the absence of haematological changes excluded the possibility of lead poisoning.

(4) Lead Poisoning.-For comparison four industrial workers who had developed lead colic through exposure to lead dust were studied. One (L.H.) had been symptom-free for two weeks when investigated. The others had blue "lead lines" on the gums and all had anaemia and basophilic stippling of the red cells. No signs of nervous involvement could be detected.

Intramuscular injections of B.A.L. were given to a few patients in groups (1) and (2) as a therapeutic trial measure and to provide a possible means of 
assessing the deposits of lead in soft tissue by observing its effect on urinary lead excretion.

\section{Analytical Methods}

Determination of Lead.-An absorptiometric " dithizone" micro-method which is more sensitive, convenient and selective than most previous methods was developed for these investigations and will be published in detail elsewhere (Butler and Irving, 1952).

Its sensitivity is such that an analysis can be performed on $20 \mathrm{ml}$. of urine, $5 \mathrm{ml}$. of blood, $5-10 \mathrm{ml}$. of cerebrospinal fluid, $400 \mathrm{mg}$. of dried soft tissue or $100 \mathrm{mg}$. of dried bone after "wet" ashing.

The utilization of the reversion technique introduced by Irving, Andrew, and Risdon (1948, 1949), besides eliminating several of the impractical requirements of most published methods, viz. a standard solution of this notoriously unstable reagent and a rigid control of the $p \mathrm{H}$ of extraction and the concentration of other coloured species present, enables an efficient separation of lead from up to ten times as much bismuth to be achieved.

The possibility of interference from bismuth is of considerable importance in investigations of this nature. While the traces of this metal which are present in most normal human fluids and tissues may not be sufficient to lead to significant errors if they are not removed, the presence of bismuth cannot be safely ignored when dealing with tissue samples, particularly bone, from hospital patients, since it is the basis of many pharmaceutical preparations such as may be prescribed for disseminated sclerosis.

The precautions taken to minimize contamination by adventitious traces of lead followed current practice, and blanks in the region of $0.2 \mu \mathrm{g}$. were consistently obtained.

All the glass apparatus was of Pyrex, and was specially cleaned before use with caustic soda solution and concentrated nitric acid (boiling where possible) and then rinsed thoroughly with tap, distilled, and lead-free, glass-distilled water. Stainless steel needles used for the collection of blood were cleaned by boiling with dilute acetic acid and rinsing with water as described above.

Concentrated acids, ammonia, and carbon tetrachloride (A.R. grade) were redistilled in all Pyrex apparatus, and salts (A.R. grade) were purified by extracting their aqueous solutions with a carbon tetrachloride solution of dithizone.

Collection of Specimens.-Urine was collected over 24 hours rather than over shorter periods, since Webster (1941) and Kehoe (1947) have shown that there is a marked diurnal variation in urinary lead excretion. It was passed into a Pyrex 2- or 3-1. bottle with the aid of a funnel where necessary. Any precipitates were dissolved by the addition of hydrochloric acid before samples were taken for analysis.

Blood was collected by venipuncture in an ungreased Pyrex syringe and then expelled into a Pyrex tube provided with a stopper and containing a little solid ammonium citrate as an anticoagulant. Cerebrospinal fluid was taken by lumbar puncture with a stainless steel needle and collected in a Pyrex tube after discarding the first few drops.

Large samples of soft tissue were taken at necropsy in the normal way and afterwards uncontaminated specimens were removed from the interior of these samples with specially cleaned instruments and placed in metalfree Pyrex dishes. Pyrex glass instruments were used for E.D., W.W., T.A., and M.B. while those employed for taking the other specimens were made of stainless steel.

Discs of tibial cortex weighing 1-2 g. were removed with a trephine and placed in metal-free Pyrex tubes. The teeth analysed were all unfilled, and, since the distribution of lead in teeth is unknown, only whole, non-carious specimens were collected. They were put into metal-free Pyrex tubes immediately after extraction and washed with hot, metal-free water.

All tissue was dried by vacuum desiccation and heating at $110^{\circ} \mathrm{C}$.

Estimation of Coproporphyrin in Urine.-The method was essentially that of Schwartz, Hawkinson, Cohen, and Watson (1947). The coproporphyrin in a 100-ml. sample of urine (less for patients with lead poisoning) was extracted with an ether-acetic acid mixture and after separation from other porphyrins was estimated fluorimetrically using a Pulfrich photometer under ultra-violet light and safranin as a standard (Jope and O'Brien, unpublished).

\section{Results and Discussion}

The results obtained are given for individual subjects in Tables I-IV and VI, and in Tables V and VII are collectively compared with the normal ranges established by other workers who used less refined methods of comparable accuracy for estimating lead.

The neurological cases (groups 1 and 2) will now be considered in relation to the possibility of lead poisoning or an abnormal absorption or mobilization of lead. The severe disability of some of these patients limited the number of specimens which could be studied.

There was in no case either a history of colic or vomiting or evidence of anaemia or abnormal basophilic stippling of the red cells. An unusual exposure to lead could be traced for only two patients, F.F. and F.R., and both had disseminated sclerosis. The former had been a painter but his urinary excretion of lead $(50 \mu \mathrm{g} . / 24 \mathrm{hrs}$. $)$ was similar to that of other patients (Table I). F.R. had been exposed to lead dust in a car factory for three months just tefore the onset of symptoms. The concentration of lead in a sample of cerebral white matter obtained at necropsy nine years later was not abnormally high (Table VI).

Urinary Excretion of Lead.-The excretion of more than $100 \mu \mathrm{g}$. of lead in 24 hours is taken as 
TABLE I

VALUES FOR LEAD CONCENTRATION IN BLOOD AND C.S.F. OF PATIENTS WITH DISSEMINATED SCLEROSIS AND FOR URINARY EXCRETION OF LEAD AND COPROPORPHYRIN

\begin{tabular}{|c|c|c|c|c|c|}
\hline \multirow[b]{2}{*}{ Case } & \multicolumn{3}{|c|}{ 24-hr. Urinary Excretion } & \multirow{2}{*}{$\begin{array}{l}\text { Blood } \\
(\mu \mathrm{gg} . \mathrm{Pb} / \\
100 \mathrm{ml} .)\end{array}$} & \multirow{2}{*}{$\begin{array}{c}\text { C.S.F. } \\
(\mu \mathrm{g} . \mathrm{Pb} \\
100 \mathrm{ml} .)\end{array}$} \\
\hline & Vol. (ml.) & $\mathrm{Pb}(u \mathrm{~g})$. & $\begin{array}{c}\text { Copro- } \\
\text { porphyrin } \\
(\mu \mathrm{g} .)\end{array}$ & & \\
\hline $\begin{array}{c}\text { H.S. } \dagger \\
, "\end{array}$ & $\begin{array}{l}820 \\
730 \\
\end{array}$ & $\begin{array}{c}5 \\
46^{*} \\
\end{array}$ & 二 & 二 & $<4$ \\
\hline $\begin{array}{c}\text { E.C. } \\
, "\end{array}$ & $\begin{array}{l}1,300 \\
1,080 \\
\end{array}$ & $\begin{array}{l}47 \\
97^{*} \\
\end{array}$ & $=$ & $=$ & $=$ \\
\hline $\begin{array}{c}\text { L.S. } \\
, .\end{array}$ & $\begin{array}{l}1,460 \\
2,060 \\
\end{array}$ & $25^{*}$ & $=$ & $=$ & 二 \\
\hline $\begin{array}{c}\text { W.H. } \\
, \quad\end{array}$ & $\begin{array}{l}1,530 \\
2,130 \\
\end{array}$ & $\begin{array}{r}35 \\
43 \\
\end{array}$ & - & 二 & 二 \\
\hline$\overline{\text { F.F. }}$ & 1,280 & 50 & - & - & - \\
\hline E.P. & 1,590 & 9 & - & 11 & - \\
\hline $\begin{array}{c}\text { V.B. } \\
, "\end{array}$ & $\begin{array}{l}2,700 \\
2,640 \\
\end{array}$ & 97 & $\overline{53}$ & 二 & 20 \\
\hline J.L.† & 1,010 & 43 & - & 20 & $2 \cdot 5$ \\
\hline $\begin{array}{c}\overline{\text { R.M. }} \\
, \bar{\prime} \\
, "\end{array}$ & $\begin{array}{l}1,350 \\
1,320 \\
1,090 \\
1,730\end{array}$ & $\begin{array}{r}8 \\
28 \\
18 \\
- \\
\end{array}$ & $\begin{array}{r}25 \\
103 \\
183 \\
190 \\
\end{array}$ & $\begin{array}{l}7 \\
-\end{array}$ & $\begin{array}{l}2 \\
-\end{array}$ \\
\hline $\begin{array}{l}\text { A.B. } \\
-"\end{array}$ & $\begin{array}{l}1,710 \\
2,200 \\
\end{array}$ & 5 & $\begin{array}{l}142 \\
105 \\
\end{array}$ & $\begin{array}{l}6.5 \\
-\end{array}$ & $<1$ \\
\hline $\begin{array}{c}\text { M.L. } \\
\quad,\end{array}$ & $\begin{array}{l}1,080 \\
1,810 \\
\end{array}$ & $\begin{array}{l}31 \\
48 \\
\end{array}$ & $\begin{array}{l}4 \\
6 \\
\end{array}$ & 19 & 二 \\
\hline A. $R$. & 1,105 & $25 \cdot 5$ & $31 \cdot 5$ & $10 \cdot 5$ & - \\
\hline D.M. & 690 & 19 & 32 & 8 & - \\
\hline K.P. & 935 & 25 & 28 & $6 \cdot 5$ & - \\
\hline R.A. ${ }^{\dagger}$ & 2,650 & 73 & - & - & - \\
\hline P.A. & 1,080 & - & 108 & 2 & $<1$ \\
\hline B.A. & 1,880 & - & 60 & 8 & $5 \cdot 5$ \\
\hline I.S. & 1,590 & - & 66 & - & - \\
\hline H.W. & 490 & - & 53 & - & - \\
\hline S.L. ${ }^{\dagger}$ & 410 & - & 36 & - & - \\
\hline D.B. & 1,700 & - & 48 & - & 7 \\
\hline M.M. & 2,150 & - & 43 & 一 & - \\
\hline M.K. $\dagger$ & - & - & - & 35 & - \\
\hline W.S. & - & - & - & 15 & 4 \\
\hline C.B. & 二 & - & $=$ & 27 & - \\
\hline $\mathrm{w} . \mathrm{w}$. & - & - & - & - & 7 \\
\hline B.B. & - & - & - & - & 12 \\
\hline M.R. & - & - & - & - & 27 \\
\hline S.M. & - & - & - & - & 2 \\
\hline D.F. & - & - & - & - & 2 \\
\hline M.H. & - & - & - & - & 12 \\
\hline
\end{tabular}

Suspected cases indicated by.$+{ }^{*}$ denotes that B.A.L. was injected during the collection of the specimen.
TABLE II

VALUES FOR LEAD CONCENTRATION IN BLOOD AND C.S.F. OF PATIENTS WITH VARIOUS NEUROLOGICAL DISEASES AND FOR URINARY EXCRETION OF LEAD AND COPROPORPHYRIN

\begin{tabular}{|c|c|c|c|c|c|c|}
\hline \multirow[b]{2}{*}{ Case } & \multirow[b]{2}{*}{ Diagnosis } & \multicolumn{3}{|c|}{$\begin{array}{l}\text { 24-hr. Urinary } \\
\text { Excretion }\end{array}$} & \multirow[b]{2}{*}{$\begin{array}{r}\text { Blood } \\
-(\mu \mathrm{g} . \mathrm{Pb} / \\
-100 \mathrm{ml} .)\end{array}$} & \multirow{2}{*}{$\begin{array}{l}\text { C.S.F. } \\
(\mu g . \mathrm{Pb} / \\
100 \mathrm{ml} .)\end{array}$} \\
\hline & & $\underset{(\mathrm{ml} .)}{\text { Volume }}$ & $\begin{array}{c}\mathrm{Pb} \\
(\mu \mathrm{g} .)\end{array}$ & \begin{tabular}{|c|} 
Copro- \\
porphy- \\
rin \\
$(\mu g)$.
\end{tabular} & & \\
\hline W.L. & $\begin{array}{l}\text { Spastic para- } \\
\text { plegia }\end{array}$ & $\begin{array}{l}1,770 \\
1,220\end{array}$ & $\begin{array}{c}64 \\
195^{*}\end{array}$ & 二 & 二 & $\overline{-}$ \\
\hline L.B. & $\begin{array}{l}\text { Spastic para- } \\
\text { plegia }\end{array}$ & $\begin{array}{l}1,390 \\
2,000\end{array}$ & 412 & 二 & 二 & $\overline{-}$ \\
\hline E.S. & $\begin{array}{l}\text { Spastic para- } \\
\text { plegia }\end{array}$ & $\begin{array}{l}1,770 \\
1,970\end{array}$ & $\begin{array}{l}25 \\
82^{*}\end{array}$ & 二 & 二 & 二 \\
\hline R.A. & $\begin{array}{l}\text { Familial para- } \\
\text { plegia }\end{array}$ & $\begin{array}{l}1,100 \\
1,110\end{array}$ & $\begin{array}{c}5 \\
16^{*}\end{array}$ & $\begin{array}{l}16 \\
26\end{array}$ & 二 & E \\
\hline O.N. & $\begin{array}{l}\text { Post-vaccinal } \\
\text { encephalo- } \\
\text { pathy }\end{array}$ & 1,335 & 52 & - & 21 & 6 \\
\hline H.F. & $\begin{array}{l}\text { Spinal cord } \\
\text { disease }\end{array}$ & 1,820 & 38 & 53 & $13 \cdot 5$ & - \\
\hline M.R. & $\begin{array}{l}\text { Ascending } \\
\text { myelitis }\end{array}$ & 260 & - & 9 & - & - \\
\hline M.C. & $\begin{array}{l}\text { Myelopathy } \\
\text { ? cause }\end{array}$ & 950 & - & 18 & - & - \\
\hline L.T. & $\begin{array}{l}\text { Cerebellar } \\
\text { ataxia }\end{array}$ & - & - & - & - & 26 \\
\hline A.D. & $\begin{array}{l}\text { Friedreich's } \\
\text { ataxia }\end{array}$ & - & - & - & 3 & - \\
\hline B.S. & $\begin{array}{l}\text { Friedreich's } \\
\text { ataxia }\end{array}$ & - & - & - & - & 2 \\
\hline $\begin{array}{l}\overline{\text { C.W. }} \\
\text { (Age 7) }\end{array}$ & $\begin{array}{c}\text { Schilder's } \\
\text { disease }\end{array}$ & $\begin{array}{r}600 \\
800 \\
1,100\end{array}$ & $\begin{array}{l}13 \\
26^{*} \\
10\end{array}$ & 二 & 二 & $\bar{z}$ \\
\hline $\begin{array}{l}\text { D.E. } \\
\text { (Age 4) }\end{array}$ & $\begin{array}{l}\text { Schilder's } \\
\text { disease }\end{array}$ & - & - & - & - & $<2$ \\
\hline C.B. & $\begin{array}{l}\text { Peripheral } \\
\text { neuritis }\end{array}$ & $\begin{array}{r}1,180 \\
990\end{array}$ & $\begin{array}{l}23 \\
46^{*}\end{array}$ & 二 & 二 & 三 \\
\hline N.W. & $\begin{array}{l}\text { Peripheral } \\
\text { neuritis }\end{array}$ & $\begin{array}{l}2,010 \\
1,440 \\
\end{array}$ & $\begin{array}{c}36 \\
126^{*}\end{array}$ & 二 & 二 & 二 \\
\hline J.D. & $\begin{array}{c}\text { Peripheral } \\
\text { neuritis }\end{array}$ & 1,750 & 5 & - & - & 5 \\
\hline L.R. & $\begin{array}{c}\begin{array}{c}\text { Peripheral } \\
\text { neuritis }\end{array} \\
\end{array}$ & 1,470 & 30 & 7 & - & - \\
\hline T.T. & $\begin{array}{c}\text { Peripheral } \\
\text { neuritis }\end{array}$ & 1,510 & 10 & - & - & - \\
\hline H.W. & $\begin{array}{c}\text { Peripheral } \\
\text { neuritis }\end{array}$ & 2,270 & 88 & - & - & 23 \\
\hline M.W. & $\begin{array}{c}\text { Peripheral } \\
\text { neuritis }\end{array}$ & 1,620 & - & 97 & - & - \\
\hline T.E. & $\begin{array}{l}\text { Chronic } \\
\text { neuritis } \\
\text { with } \\
\text { paralysis }\end{array}$ & - & - & - & 13 & - \\
\hline T.W. & $\begin{array}{l}\text { Shoulder } \\
\text { girdle } \\
\text { neuritis }\end{array}$ & 1,740 & 62 & - & 16 & 32 \\
\hline W.M. & $\begin{array}{c}\text { Local } \\
\text { neuritis }\end{array}$ & 2,690 & 5 & - & - & 2 \\
\hline
\end{tabular}

[Continued on next pagc 
TABLE II-continued

\begin{tabular}{|c|c|c|c|c|c|c|}
\hline \multirow[b]{2}{*}{ Case } & \multirow[b]{2}{*}{ Diagnosis } & \multicolumn{3}{|c|}{$\begin{array}{c}\text { 24-hr. Urinary } \\
\text { Excretion }\end{array}$} & \multirow{2}{*}{$\begin{array}{c}\text { Blood } \\
(\mu \mathrm{g} . \mathrm{Pb} / \\
100 \mathrm{ml} .)\end{array}$} & \multirow{2}{*}{$\begin{array}{l}\text { C.S.F. } \\
(\mu \mathrm{g} . \mathrm{Pb} \\
100 \mathrm{ml} .)\end{array}$} \\
\hline & & $\begin{array}{l}\text { Volume } \\
\text { (ml.) }\end{array}$ & $\underset{(\mu \mathrm{g} .)}{\mathbf{P b}}$ & $\left|\begin{array}{c}\text { Copro- } \\
\text { porphy- } \\
\text { rin } \\
(\mu \mathrm{g} .)\end{array}\right|$ & & \\
\hline E.H. & ? local neuritis & 2,860 & 50 & 63 & 20 & 一 \\
\hline J.W. & $\begin{array}{l}\text { Primary } \\
\text { sensory } \\
\text { neuropathy }\end{array}$ & - & 一 & 一 & - & 9 \\
\hline W.C. & $\begin{array}{l}\text { Acute } \\
\text { infective } \\
\text { polyneuritis }\end{array}$ & 一 & - & - & - & 8 \\
\hline N.W. & $\begin{array}{l}\text { Motor neuron } \\
\text { disease }\end{array}$ & 1,120 & 67 & 一 & 一 & - \\
\hline R.S. & $\begin{array}{l}\text { Motor neuron } \\
\text { disease }\end{array}$ & 720 & 12 & - & - & 8 \\
\hline W.G. & $\begin{array}{l}\text { Motor neuron } \\
\text { disease }\end{array}$ & 1,470 & - & 125 & - & - \\
\hline V.G. & $\begin{array}{c}\text { Motor neuron } \\
\text { disease }\end{array}$ & 一 & - & - & 20 & 10 \\
\hline F.A. & $\begin{array}{c}\begin{array}{c}\text { Motor neuron } \\
\text { disease }\end{array} \\
\end{array}$ & - & - & 一 & 12 & 2 \\
\hline J.P. & $\begin{array}{l}\text { Motor neuron } \\
\text { disease }\end{array}$ & - & - & 一 & 21 & 2 \\
\hline W.H. & $\begin{array}{l}\text { Motor neuron } \\
\text { disease }\end{array}$ & - & - & 一 & - & 2 \\
\hline K.L. & $\begin{array}{l}\text { Motor neuron } \\
\text { disease }\end{array}$ & - & 一 & 一 & - & 9 \\
\hline A.B-C. & $\begin{array}{l}\text { ? Motor } \\
\text { neuronitis } \\
+\quad \text { arthritis } \\
\end{array}$ & - & - & - & 31 & $4 \cdot 5$ \\
\hline M.K. & $\begin{array}{c}\text { Peroneal } \\
\text { muscular } \\
\text { atrophy }\end{array}$ & $\begin{array}{r}1,370 \\
870\end{array}$ & $\begin{array}{l}41 \\
74 *\end{array}$ & - & - & - \\
\hline A.T. & $\begin{array}{l}\text { Muscular } \\
\text { dystrophy }\end{array}$ & 2,115 & 89 & - & 22 & 4 \\
\hline A.I. & $\begin{array}{l}\text { Muscular } \\
\text { dystrophy }\end{array}$ & - & - & - & 28 & 4 \\
\hline A.T. & $\begin{array}{l}\text { Muscular } \\
\text { dystrophy }\end{array}$ & - & - & - & 27 & - \\
\hline W.G. & $\begin{array}{l}\text { Muscle } \\
\text { wasting } \\
\text { ? cause }\end{array}$ & - & 一 & - & - & $6 \cdot 5$ \\
\hline S.W. & $\begin{array}{l}\text { Wilson's } \\
\text { disease }\end{array}$ & $\begin{array}{l}1,290 \\
1,605 \\
1,120 \\
1,960 \\
1,490\end{array}$ & $\begin{array}{r}18 \\
12 \\
25 \\
25 \\
5\end{array}$ & $\begin{array}{l}98 \\
46 \\
12 \\
20 \\
12 \cdot 5\end{array}$ & $\begin{array}{l}10 \\
11 \\
17 \\
- \\
\end{array}$ & $\begin{array}{l}E \\
z\end{array}$ \\
\hline C.B. & $\begin{array}{c}\text { Wilson's } \\
\text { disease }\end{array}$ & - & - & - & 6 & - \\
\hline G.D. & $\begin{array}{l}\text { ? Wilson's } \\
\text { disease }\end{array}$ & 3,765 & 52 & 64 & 11 & - \\
\hline W.T. & $\begin{array}{r}\text { Congenital } \\
\text { athetosis }\end{array}$ & $\begin{array}{r}940 \\
2,180 \\
1,950 \\
\end{array}$ & $\begin{array}{l}\overline{25} \\
53^{*}\end{array}$ & $\begin{array}{l}134 \\
100 \\
125 \\
\end{array}$ & E & E \\
\hline G.G. & $\begin{array}{l}\text { Choreo- } \\
\text { athetosis }\end{array}$ & $\begin{array}{l}1,490 \\
1,070\end{array}$ & $\begin{array}{l}24 \\
34 *\end{array}$ & $\begin{array}{l}98 \\
14\end{array}$ & - & - \\
\hline H.M. & $\begin{array}{c}\text { Parkinson's } \\
\text { disease }\end{array}$ & $\begin{array}{l}1,690 \\
1,270 \\
\end{array}$ & $\begin{array}{l}17 \\
54^{*} \\
\end{array}$ & 二 & - & - \\
\hline $\begin{array}{l}\text { M.R. } \\
\text { (Age 13) }\end{array}$ & $\begin{array}{c}\text { Charcot- } \\
\text { Marie } \\
\text { disease }\end{array}$ & 1,280 & 55 & 21 & 19.5 & - \\
\hline
\end{tabular}

TABLE II-continued

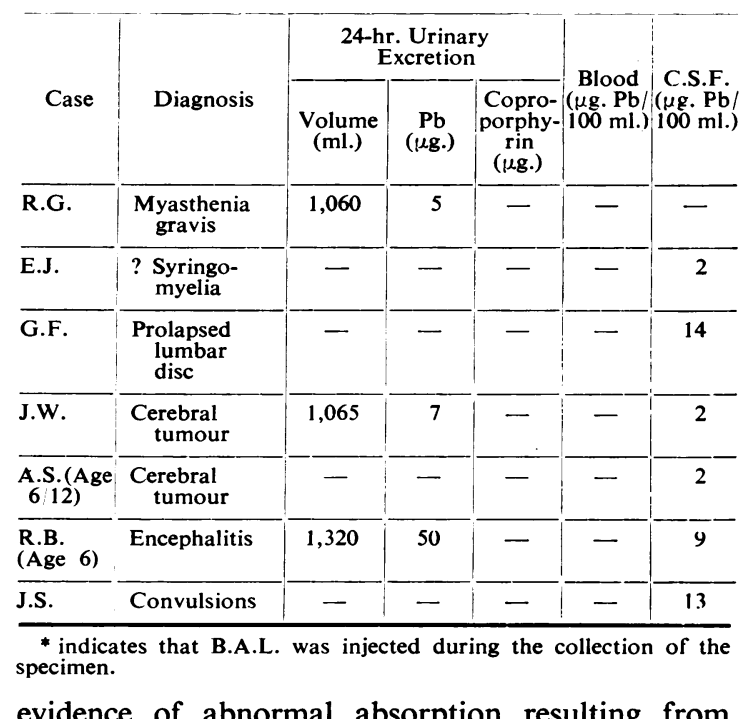

evidence of abnormal absorption resulting from unusual exposure. It may also indicate the mobilization of tissue deposits providing the mobilized lead is excreted.

No definite level above this limit can be associated with the onset or disappearance of symptoms of lead poisoning, and the excretion of $100-200 \mu \mathrm{g}$. of lead may occur in the absence of symptoms and haematological changes. This is illustrated by the values for the excretion of B.B. and C.H. (Table III) and the patients with lead colic (Table IV).

Past workers have shown that an abnormal urinary lead excretion is the first sign of abnormal absorption, occurring before an elevation in coproporphyrin excretion (Johnson and Whitman, 1950) and blood lead concentration (Kehoe, Thamann, and Cholak, 1935). The results for B.B., a solderer, are in agreement with these findings. After poisoning the elimination of the excess lead from the tissues is gradual. J.L. (Table IV) had an abnormal lead excretion $(160 \mu \mathrm{g} . / 24 \mathrm{hrs}$.) over three months after his blood film had become normal. The determination of urinary lead excretion is thus a very sensitive test of abnormal absorption and probably of mobilization.

It is apparent from Table $\mathrm{V}$ that the excretion of all the neurological patients was within the normal limits. The average excretions for the two groups were almost identical (33 and $32 \mu \mathrm{g} . \mathrm{Pb} / 24 \mathrm{hrs}$. respectively) and were less than the output of all the patients with abnormal exposure (Table III).

These figures, therefore, provide no evidence of an abnormal absorption of lead, of a mobilization of it, or of a past attack of lead poisoning in any 
subject with chronic neurological disease. The majority of the patients with disseminated sclerosis were investigated when showing active symptoms, and in three cases (V.B., J.L., R.M.) the duration of the disease was less than three months. The second group includes a boy, (C.W.) aged 7, with Schilder's disease, which is pathologically very similar to swayback in lambs. Verhaart (1941) described a similar case with high concentrations of lead in the brain and liver, but could not identify a hazard. It is interesting to note also that the high urinary copper excretion in Wilson's disease is not accompanied by an abnormal lead excretion. Subsequent work (unpublished) has shown that the zinc output is also normal in this disease.

The administration of B.A.L. to 14 neurological patients (three with disseminated sclerosis) produced a significant increase in the 24-hourly excretion of lead (usually twofold-fourfold) in each case (Tables I and II). Four intramuscular injections of $100 \mathrm{mg}$. of B.A.L. in propylene glycol were given at three-hourly intervals, the first at the beginning of the 24-hour period. The amount by which the urinary lead excretion was increased (an abnormal excretion was produced in only two instances) does not indicate the presence of large amounts of lead in soft tissue.

This mobilization of lead, which may have been accompanied by an increased excretion of the essential metals copper and zinc (unpublished work), produced no clinical change. It may be mentioned that Furmanski (1948) claimed that smaller doses of B.A.L. had a beneficial effect on patients with severe peripheral neuropathy, but was reluctant to consider this to be due to the removal of some intoxicating heavy metal.

Lead in Blood.- - Lead has been found in the blood of normal unexposed subjects in concentrations up to $89 \mu \mathrm{g} . / 100 \mathrm{ml}$. (Table V), and, according to Cantarow and Trumper (1944), the majority have concentrations below $60 \mu \mathrm{g} . / 100 \mathrm{ml}$. As with urinary lead excretion there is no definite threshold value at which symptoms of poisoning appear in exposed people. The patients with lead colic had concentrations of 85 to $96 \mu \mathrm{g}$. $/ 100 \mathrm{ml}$. when showing symptoms, and after clinical remission the two patients investigated showed values of 65 and $62 \mu \mathrm{g} . / 100 \mathrm{ml}$. (Table IV). Six weeks afterwards when their blood films were normal these levels had fallen to $44-56 \mu \mathrm{g} . / 100 \mathrm{ml}$. Two subjects with unusual exposure showed values within this range (Table III).

The highest concentration found in a neurological patient (Tables I and II) was $35 \mu \mathrm{g} . / 100 \mathrm{ml}$. The
TABLE III

VALUES FOR LEAD CONCENTRATION IN BLOOD OF MISCELLANEOUS PATIENTS WITH UNUSUAL EXPOSURE TO LEAD AND FOR URINARY EXCRETION OF LEAD AND COPROPORPHYRIN

\begin{tabular}{|c|c|c|c|c|c|c|}
\hline \multirow[b]{2}{*}{ Case } & \multirow[b]{2}{*}{ Occupation } & \multirow[b]{2}{*}{ Symptoms } & \multicolumn{3}{|c|}{$\begin{array}{l}\text { 24-hr. Urinary } \\
\text { Excretion }\end{array}$} & \multirow{2}{*}{$\begin{array}{c}\text { Blood } \\
(\mu \mathrm{g} . \mathrm{Pb} / \\
100 \mathrm{ml})\end{array}$} \\
\hline & & & $\begin{array}{l}\text { Vol. } \\
\text { (ml.) }\end{array}$ & $\underset{(\mu \mathrm{g} .)}{\mathbf{P b}}$ & $\begin{array}{l}\text { Copro- } \\
\text { porphy- } \\
\text { rin } \\
(\mu \mathrm{g} .)\end{array}$ & \\
\hline H.L. & $\begin{array}{c}\text { Paint sprayer } \\
\text { (16 years) }\end{array}$ & $\begin{array}{l}\text { Paraesthesia } \\
\text { of legs }\end{array}$ & 2,980 & 45 & 40 & $12 \cdot 5$ \\
\hline B.C. & Painter & $\begin{array}{l}\text { Paraesthesia } \\
\text { of left leg, } \\
\text { vomiting }\end{array}$ & 1,375 & - & 110 & - \\
\hline B.B. & $\begin{array}{c}\text { Solderer } \\
\text { years })\end{array}$ & $\begin{array}{l}\text { Muscular } \\
\text { weakness } \\
\text { in arms }\end{array}$ & 1,235 & 116 & 30 & 51 \\
\hline P.A. & Painter & Colic & 1,310 & 42 & - & - \\
\hline J.R. & $\begin{array}{l}\text { Paint sprayer } \\
\text { (1 year) }\end{array}$ & Colic & 1,200 & 72 & 72 & - \\
\hline G.S. & $\begin{array}{c}\text { Painter } \\
\text { years })\end{array}$ & $\begin{array}{l}\text { Abdominal } \\
\text { pains, } \\
\text { muscular } \\
\text { rigidity }\end{array}$ & 2,045 & 81 & 245 & - \\
\hline C.H. & $\begin{array}{l}\text { Butcher } \\
\text { (heavy beer } \\
\text { drinker for } \\
38 \text { years) }\end{array}$ & $\begin{array}{l}\text { Muscular } \\
\text { weakness } \\
\text { in legs and } \\
\text { fingers }\end{array}$ & 1,730 & 125 & 110 & 41 \\
\hline
\end{tabular}

TABLE IV

VALUES FOR LEAD CONCENTRATION IN BLOOD AND C.S.F. OF PATIENTS WITH LEAD COLIC AND FOR URINARY EXCRETION OF LEAD AND COPROPORPHYRIN

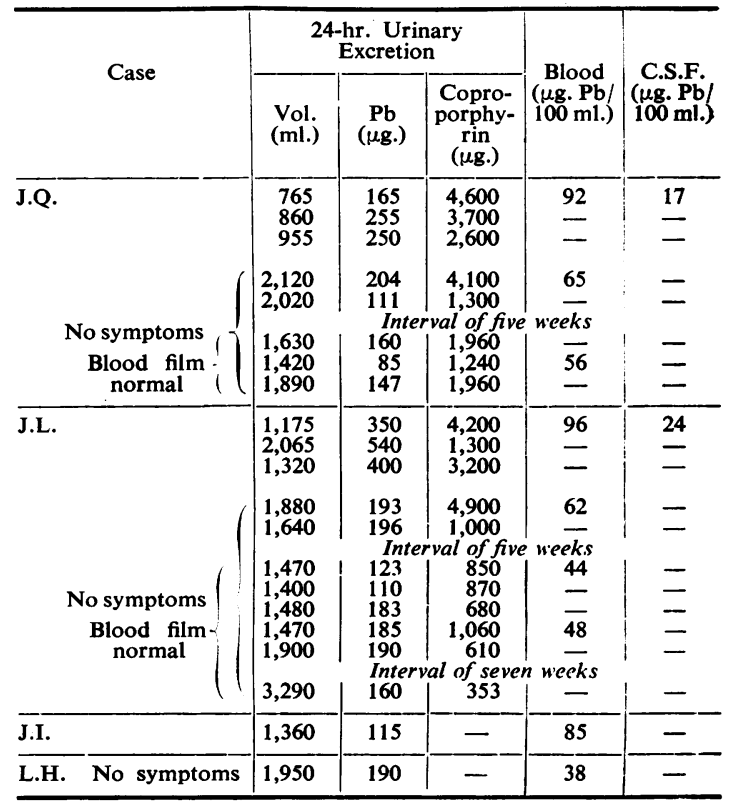


TABLE V

COMPARISON OF VALUES FOR LEAD CONCENTRATION IN BLOOD AND C.S.F. AND FOR URINARY EXCRETION OF LEAD AND COPROPORPHYRIN WITH NORMAL RANGES

\begin{tabular}{|c|c|c|c|c|c|c|c|c|c|}
\hline \multirow{2}{*}{\multicolumn{5}{|c|}{ Author }} & \multirow[b]{2}{*}{ Subjects } & \multicolumn{2}{|c|}{ 24-hr. Urinary Excretion } & \multirow{2}{*}{$\stackrel{\text { Blood }}{(\mu \mathrm{g} . \mathrm{Pb} / 100 \mathrm{ml} .)}$} & \multirow{2}{*}{$\begin{array}{l}\text { C.S.F. } \\
(\mu \mathrm{g} . \mathrm{Pb} / 100 \mathrm{ml} .)\end{array}$} \\
\hline & & & & & & $\mu g . \mathrm{Pb}$. & $\begin{array}{l}\text { ug. Copro- } \\
\text { porphyrin }\end{array}$ & & \\
\hline \multicolumn{5}{|c|}{$\begin{array}{l}\text { Cantarow and Trumper (1944) and authors } \\
\text { since } 1933 \text { cited }\end{array}$} & Normals & $0-100$ & - & $0-80$ & - \\
\hline \multicolumn{5}{|c|}{ Watson and Larson (1947) and authors cited } & Normals & - & $0-120$ & - & 一 \\
\hline \multicolumn{2}{|c|}{ Letonoff and others (1940) } & . & $\cdots$ & . & Normals & - & - & $9-50$ & - \\
\hline Chalmers (1940) & $\ldots$ & . & . & $\ldots$ & Normals & - & - & $36-89$ & 一 \\
\hline Brown (1946) & $\ldots$ & . & $\cdots$ & $\ldots$ & Normals & - & - & $11-81$ & - \\
\hline \multicolumn{2}{|c|}{ Schmitt and Basse (1937) } & . & $\cdots$ & $\bar{\cdots}$ & Normals & - & - & - & $15-38$ \\
\hline \multicolumn{3}{|c|}{ Cantarow and Trumper (1944) } & $\cdots$ & . & $\begin{array}{l}\text { Patients with no neuro- } \\
\text { logical symptoms }\end{array}$ & - & 一 & 一 & $1-40$ \\
\hline Butler (this paper) & $\cdots$ & $\cdots$ & . & $\ldots$ & Patients with D.S. (Table I) & $\begin{array}{l}5-97 \\
(33)\end{array}$ & $\begin{array}{l}4-190 \\
(69 \cdot 5)\end{array}$ & $\begin{array}{r}2-35 \\
(13 \cdot 5)\end{array}$ & $\begin{array}{c}<1-27 \\
(\backsim 7)\end{array}$ \\
\hline , & . & $\ldots$ & . & 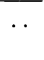 & $\begin{array}{l}\text { Miscellaneous neurological } \\
\text { patients (Table II) }\end{array}$ & $\begin{array}{l}5-89 \\
(32)\end{array}$ & $\begin{array}{l}7-134 \\
(55)\end{array}$ & $\begin{array}{l}3-31 \\
(17)\end{array}$ & $\begin{array}{l}<2-32 \\
(\sim 8)\end{array}$ \\
\hline , & $\cdots$ & $\cdots$ & . & $\cdots$ & $\begin{array}{l}\text { Patients with exposure } \\
\text { (Table III) }\end{array}$ & $42-125$ & $30-245$ & $12 \cdot 5-51$ & - \\
\hline , & $\cdots$ & $\cdots$ & . & $\cdots$ & $\begin{array}{l}\text { Patients with lead colic } \\
\text { (Table IV) }\end{array}$ & $115-540$ & $1,300-4,600$ & $85-96$ & 17 and 24 \\
\hline , & $\cdots$ & $\cdots$ & . & $\cdots$ & $\begin{array}{l}\text { Patients with normal blood } \\
\text { film after } \mathrm{Pb} \text { colic (Table } \\
\text { IV) }\end{array}$ & $85-190$ & $353-1,960$ & $44-56$ & - \\
\hline
\end{tabular}

(The figures given in brackets are average values)

TABLE VI

VALUES FOR LEAD CONCENTRATION (P.P.M. DRY WEIGHT) IN TISSUES OF PATIENTS WITH NEUROLOGICAL DISEASE

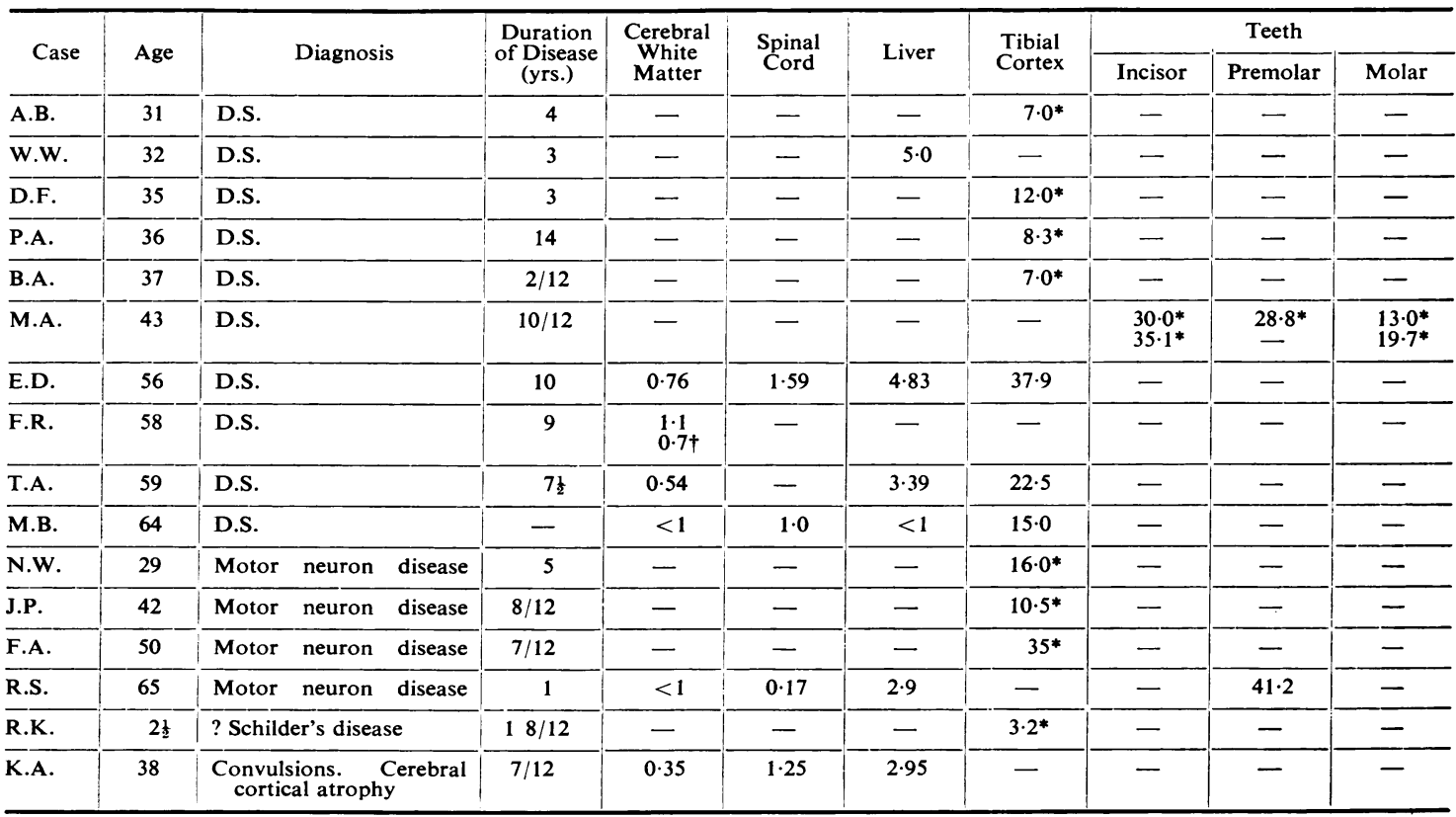

Additional results : W.W., Rib 9.5. M.B., Kidney 0.8.

* Specimens obtained by biopsy.

$\dagger$ This result is for a specimen containing a plaque of demyelination. 
TABLE VII

COMPARISON OF VALUES FOR LEAD CONCENTRATION IN TISSUES (P.P.M. DRY WEIGHT) WITH THOSE OF OTHER WORKERS

\begin{tabular}{|c|c|c|c|c|c|c|c|c|}
\hline \multicolumn{2}{|l|}{ Author } & Diagnosis & Brain & Liver & Kidney & Tibia & Teeth & Rib \\
\hline \multicolumn{2}{|c|}{$\begin{array}{l}\text { Hansmann and Perry (1940) } \\
\text { and authors cited }\end{array}$} & $\begin{array}{l}\text { Various (no exposure } \\
\text { to } \mathrm{Pb} \text { or mobiliza- } \\
\text { tion) }\end{array}$ & $0-1.99$ & $0-43 \cdot 74$ & $1 \cdot 0-110 \cdot 05$ & $20 \cdot 4-289 \cdot 5$ & $0 \cdot 15-274 \cdot 7$ & $0-86.42$ \\
\hline Riggs and others (1944) & $\ldots$ & $\begin{array}{l}\text { Other neurological } \\
\text { disease }\end{array}$ & - & - & $3 \cdot 6-11 \cdot 4$ & - & - & - \\
\hline \multicolumn{2}{|l|}{ Campbell and others $(1950) \quad \ldots$} & Normals (age 40-50) & - & - & - & - & $25 \cdot 7-95 \cdot 1$ & - \\
\hline , & $\cdots$ & Normals (age 60-70) & - & - & - & - & $74 \cdot 5-90 \cdot 3$ & - \\
\hline , & $\ldots$ & D.S. (age 60-70) & - & - & - & - & $129 \cdot 3$ & - \\
\hline Butler (this paper) & $\ldots$ & D.S. & $0 \cdot 54-1 \cdot 1$ & $<1-5$ & 0.8 & $7 \cdot 0-37 \cdot 9$ & $\begin{array}{l}13 \cdot 0-35 \cdot 1 \\
\text { (age 43) }\end{array}$ & $9 \cdot 5$ \\
\hline , & $\ldots$ & $\begin{array}{l}\text { Other neurological } \\
\text { disease }\end{array}$ & 0.35 and & 2.9 and & - & $3 \cdot 2-35$ & $\begin{array}{c}41 \cdot 2 \\
(\text { age } 64)\end{array}$ & - \\
\hline
\end{tabular}

TABLE VIII

LEAD CONTENT OF BLOOD AND TISSUE OF NEURO. LOGICAL PATIENTS

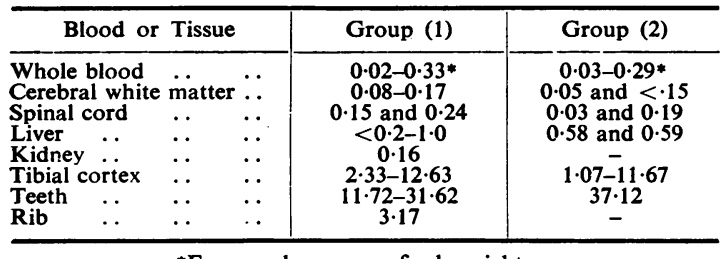

*Expressed as p.p.m. fresh weight.

average for the two groups was almost the same, viz. 13.5 and $17 \mu \mathrm{g} . / 100 \mathrm{ml}$. (Table V). These figures thus provide no evidence of abnormal absorption or mobilization.

Urinary Excretion of Coproporphyrin.--Normal healthy adults may excrete up to $120 \mu \mathrm{g}$. of coproporphyrin in their urine in 24 hours. This coproporphyrin consists of a mixture of the Types $I$ and III isomers in which the former predominates (Schwartz, Hawkinson, Cohen, and Watson, 1947). It has been established that in lead poisoning a great increase in the excretion of coproporphyrin III occurs, due probably to a disturbance in the synthesis of haemoglobin.

Waldman and Seideman (1950) and Maloof (1950) have recently confirmed the observation of de Langen and ten Berg that with exposure to lead the urinary coproporphyrin excretion becomes abnormal long before haematological changes and symptoms appear.

The coproporphyrin excretion of two of the patients with lead colic was determined and was much more abnormal than their lead excretion (Table IV). It remained high when the haematological changes disappeared, and over three months afterwards J.L. had an excretion of $353 \mu \mathrm{g} . / 24$ hours. The estimation of urinary coproporphyrin excretion is thus a sensitive test of a past attack of lead poisoning as well as of an abnormal absorption of lead.

However, this change is non-specific, and smaller elevations have been observed in poisoning by other chemicals, anaemias, infectious disease, including the common cold (Jope and O'Brien, unpublished data), and following the administration of drugs, e.g. sulphonamides and salicylates. Therefore this abnormality, like stippling, cannot be taken as a diagnostic sign of lead poisoning until abnormal amounts of lead have been demonstrated in the blood and urine.

Two patients with disseminated sclerosis (R.M. and A.B., Table I) and one with peripheral neuritis and one with congenital athetosis (W.A. and W.T., Table II) showed slightly abnormal excretions of coproporphyrin. Three consecutive specimens of urine were collected from R.M. and these contained 25,103 , and $183 \mu \mathrm{g}$. of coproporphyrin respectively. A course of histamine injections was started during the collection of the last specimen and may have been responsible for the abnormal excretion which was again observed $(190 \mu \mathrm{g}$.) five months later. It was not associated with a raised lead excretion. A.B. had been given a mixture of metallic salts, including those of cobalt, copper, chromium, manganese, beryllium, daily by mouth for several weeks, eight months before the specimens were collected.

The abnormal excretion of W.A. and W.T. could not be correlated with any pathological condition or therapy. The normal excretion of the patient with Wilson's disease (S.W.) may indicate that this is not a condition of copper poisoning. 
It is concluded that lead had not entered the blood stream in sufficient amounts to cause an increased coproporphyrin excretion in patients with disseminated sclerosis and the other neurological diseases studied.

Lead in Cerebrospinal Fluid.-The low sensitivity of older analytical methods has enabled comparatively little work to be done on the normal concentration of lead in the cerebrospinal fluid. However, the significance of the concentration of lead in this fluid in the diagnosis of lead encephalopathy is doubtful, since it appears to bear no definite relation to the symptoms (Hay, 1950) and high values may be found in lead poisoning with no neurological manifestations (Cantarow and Trumper 1944).

The concentrations found in the two groups of neurological patients (Tables I and II) were not significantly different and were all lower than the normal limit of $40 \mu \mathrm{g} . / 100 \mathrm{ml}$. suggested by past work. This value was also not exceeded in lead colic although the concentration in the blood was abnormal, a finding which has been reported in similar cases many times in the literature. A child with lead encephalopathy studied subsequently showed a cerebrospinal fluid lead concentration of $7 \mu \mathrm{g} . / 100 \mathrm{ml}$. concurrently with a blood concentration of $170 \mu \mathrm{g} . / 100 \mathrm{ml}$.

Lead in Tissues.-The results examined above do not exclude the remote possibility that in disseminated sclerosis and certain other neurological diseases lead may be intermittently released from skeletal deposits and transported to the central nervous system so quickly that the rise in blood lead concentration is merely transient and is not reflected in an increased lead and coproporphyrin excretion. An alternative theory is that the central nervous system develops an abnormal affinity for lead and retains toxic amounts from normal blood concentrations, any mobilization from bone being relatively unimportant. Clearly a final answer to this question can only be supplied by the analysis of brain and spinal cord.

The values obtained for the concentration of lead in the cerebral white matter (frontal lobe), spinal cord, and other tissues of subjects in Groups I and II are given in Table VI and are not significantly different for the two groups. Further, it is apparent from Table VII that they all lie well below the upper limits of the results recorded by previous workers for various people with no abnormal exposure to or mobilization of lead. This table does not include the results of Hijman (1935) which are considerably higher than those of all other workers. Campbell and others (1950) do not state whether their results are for dry or fresh weight.

It is of some interest to note that the lead content of five teeth from M.A., a case of disseminated sclerosis, show a dependence upon the type of tooth (Table VI). The values for tibial cortex show no regular variation with age or the duration of the disease.

In Table VIII the concentration limits for lead in the blood and tissues of the two groups of subjects expressed in p.p.m. fresh weight, are compared. In calculating these values it was assumed that the specific gravity of blood was 1.06 and the water content $(\mathrm{w} / \mathrm{w})$ of the tissues was as follows :brain and spinal cord, $85 \%$; other soft tissue, $80 \%$; bone, $66 \%$; and teeth, $10 \%$ (Hansmann and Perry).

It is obvious that there had been no significant accumulation of lead in the cerebral white matter and spinal cord. It had been retained to some extent by the liver and deposited in much larger concentrations in the skeleton, particularly in the teeth, as is normal. The values obtained for these concentrations are not consistent with the finding of Campbell and others of abnormal deposits of lead in teeth in disseminated sclerosis.

Thus the analysis of tissue taken at necropsy, has shown that in at least four cases lead had not been directly responsible for the production of the lesions of disseminated sclerosis and provided no evidence of any abnormality in the distribution of lead between the skeleton and soft tissue in this disease. Copper and zinc have also been estimated in these specimens, and these results will be presented in a separate communication together with a description of the cases and the post-mortem findings.

\section{Summary}

With an improved analytical method it was found that patients with disseminated sclerosis showed no significant difference from those with other chronic neurological diseases as regards their urinary excretion of lead and its concentration in the blood, cerebrospinal fluid, and tibial cortex, which in all cases was within the normal limits.

Patients with confirmed lead poisoning were studied for comparison and showed that an abnormally high urinary excretion of lead and coproporphyrin is maintained long after clinical remission and the disappearance of haematological changes. The coproporphyrin excretion of the two groups of neurological patients was not significantly different and with a few exceptions was within the normal range.

The injection of neurological patients with B.A.L. consistently produced an increase in urinary lead 
excretion (usually two- to fourfold). This response in terms of increased lead excretion bore no apparent relation to the diseases studied, nor did its magnitude indicate the presence of abnormal amounts of lead in circulation and soft tissue.

The lead content of necropsy samples of tissue, including brain and spinal cord, obtained from subjects whose diagnosis of disseminated sclerosis was confirmed histologically showed that lead was not responsible for the lesions in these people and that there had been no mobilization of lead from the skeleton.

It is concluded that the studies reported do not support the view that lead plays a part in the aetiology of disseminated sclerosis and certain other chronic diseases of the nervous system.

This research was suggested by Dr. W. Ritchie Russell and I am grateful to him and his staff for their cooperation and advice. My thanks are also due to Mr. J. R. P. O'Brien for many helpful suggestions and stimulating discussions ; to Messrs. B. Cooke and G. Newman for invaluable technical assistance; to Mrs. S. Harrold for carrying out some of the coproporphyrin estimations ; to Drs. P. M. Daniel and F. D. Bosanquet for necropsy material ; and to Dr. D. McAlpine (the Middlesex Hospital) for collecting teeth. I am indebted to the Medical Research Council for a personal grant and also a grant for technical assistance.

\section{REFERENCES}

Aub, J. C. (1935). J. Amer. med. Ass., 104, 87.

Boshes, B. (1935). Arch. Neurol. Psychiat., Chicago, 34, 994.

Brown, A. (1946). Quart. J. Med., n.s. 15, 77.

Butler, E. J., and Irving, H. (1952). In preparation.

Campbell, A. M. G., Herdan G., Tatlow, W. F. T., and Whittle, E. G. (1950). Brain, 73, 52.

Cantarow, A., and Trumper, M. (1944). "Lead Poisoning ". Baltimore.

Chalmers, J. N. M. (1940). Lancet, 1, 447.
Cone, W., Russel, C., and Harwood, R. U. (1934). Arch. Neurol. Psychiat., Chicago, 31, 236.

Cruickshank, D. B. (1940). Brit. dent. J., 68, 257.

Furmanski, A. R. (1948). Arch. Neurol. Psychiat., Chicago, 60, 270.

Gray, I. (1935). J. Amer. med. Ass., 104, 200.

Hansmann, G. H., and Perry, M. C. (1940). Arch. Path., Chicago, 30, 226.

Hay, W. (1950). British Journal of Industrial Medicine, $7,177$.

Hijman, A. J. (1935). Far East Ass. trop. Med.: Trans. Ninth Congr., Nanking 1934, vol. 1, p. 373.

Innes, J. R. M., and Shearer, G. D. (1940). J. comp. Path., 53, 1.

Irving, H., Andrew, G., and Risdon, E. J. (1948). Nature, Lond., 161, 805.

Risdon, E. J., and Andrew, G. (1949). J. chem. Soc., p. 537.

Johnson, W. S., and Whitman, N. E. (1950). Arch. industr. Hyg., $2,170$.

Kehoe, R. A. (1947). Occup. Med., 3, 156.

, Thamann, F., and Cholak, J. (1933). J. industr. Hyg., 15, 257.

$\longrightarrow,-\longrightarrow$ (1935). J. Amer. med. Ass., 104, 90.

Langen, C. D. de, and Berg, J. A. G. ten (1948). Acta med. scand., $130,37$.

Letonoff, T. V., Reinhold, J. G., Riggs, H. E., and Cohn, C. (1940). Amer. J. Obstet. Gynec., 40, 1017. - (1940). Industr. Engng. Chem., (Anal. Ed.), $12,280$.

Maloof, C. C. (1950). Arch. industr. Hyg., 1, 296.

Rabinowitch, I. M., Dingwall, A., and Mackay, F. H. (1933). J. biol. Chem., 103, 707.

Riggs, H. E., Letonoff, T. V., and Reinhold, J. G. (1944) Amer. J. clin. Path., 14, 175.

Schmitt, F., and Basse, W. (1937). Klin. Wschr., 16, 65.రి

Schwartz, S., Hawkinson, V., Cohen, S., and Watson, C. J. (1947). J. biol. Chem., 168, 133.

Shearer, G. D., and McDougall, E. I. (1944). J. agric. 으 겅 Sci., 34, 207.

Verhaart, W. J. C. (1941). Amer. J. Dis. Child., 61, 1246.

Waldman, R. K., and Seideman, R. M. (1950). Arch. industr. Hyg., 1, 290.

Watson, C. J., and Larson, E. A. (1947). Physiol. Rev., 27, 478.

Webster, S. H. (1941). Publ. Hlth Rep., Wash., 56, 1834.

Williams, H. B. (1939). J. Amer. med. Ass., 112, 534. 